\title{
Monitoring Metabolic Health of Dairy Cattle in the Transition Period
}

\author{
Stephen LEBLANC \\ Population Medicine, Ontario Veterinary College, University of Guelph, Canada N1G 2W1
}

\begin{abstract}
This paper reviews the importance of energy metabolism in transition dairy cows, its associations with disease and reproduction, and strategies for monitoring cows under field conditions during this critical time. Essentially all dairy cattle experience a period of insulin resistance, reduced feed intake, negative energy balance, hypocalcemia, reduced immune function, and bacterial contamination of the uterus soon before, or in the weeks after calving. One-third of dairy cows may be affected by some form of metabolic or infectious disease in early lactation. Routine, proactive actions, observations, or analysis are intended to accurately and efficiently provide early detection of problems, to provide an opportunity for investigation and intervention in order to limit the consequences and costs of health problems and reduced animal performance or welfare. Methods of early detection include monitoring of disease and culling records, feed intake, milk production, body condition, and simple metabolic tests. Methods, strategies, and interpretation of measurement of peripartum concentrations of non-esterified fatty acids (NEFA) and $\beta$ hydroxybutyrate (BHB) as indicators of aspects of energy status and disease risk are reviewed. High NEFA $(>0.4$ $\mathrm{mmol} / \mathrm{l}$ ) in the last 7 to 10 days before expected calving is associated with increased risk of displaced abomasum (DA), retained placenta, culling before 60 days in milk, and less milk production in the first 4 months of lactation. Subclinical ketosis (serum BHB > 1200 to $1400 \mu \mathrm{mol} / \mathrm{l}$ ) in the first or second week after calving is associated with increased risk of DA, metritis, clinical ketosis, endometritis, prolonged postpartum anovulation, increased severity of mastitis, and lower milk production in early lactation. There are several validated and practical tools for cow-side measurement of ketosis. Key words: Ketosis, Non-esterified fatty acid (NEFA), Reproduction, Testing, Uterine health
\end{abstract}

(J. Reprod. Dev. 56: S29-S35, 2010)

\section{Introduction-Metabolic Challenges in Peripartum Dairy Cows and Their Associations with Reproduction}

$\mathbf{T}$ his paper reviews the importance of energy metabolism in transition dairy cows, its associations with disease and reproduction, and strategies for monitoring cows under field conditions during this critical time.

The biology of dairy cow health and reproductive performance is multifactorial and complex. High producing dairy cows have been described as "metabolic athletes". However, 30 to $50 \%$ of dairy cows are affected by some form of metabolic or infectious disease around the time of calving. Dairy cattle have been selected to re-partition nutrients in support of milk production, a process described as homeorhesis [1] in which homeostatic mechanisms are at least partially and temporarily overridden, including a period of physiologic insulin resistance. Essentially all peripartum dairy cattle experience: a period of insulin resistance, reduced feed intake, negative energy balance, lipolysis, and weight loss in early lactation; hypocalcemia in the days after calving; reduced immune function for 1 to 2 weeks before, and 2 to 3 weeks after calving; and, bacterial contamination of the uterus for 2 to 3 weeks after calving. These factors, as well as dramatic changes in circulating progesterone, estrogen, and cortisol concentrations contribute to a substantial reduction of immune function, in particular of neutrophils, at this time [2, 3]. Specifically, innate immunity from neutrophils is a primary means of immune response in the uterus

Correspondence: S LeBlanc (e-mail: sleblanc@uoguelph.ca) and neutrophil migration and phagocytic and oxidative activity are associated with the risk of retained placenta (RP) [4], metritis, and endometritis [5]. Yet, while metabolic (e.g. ketosis and fatty liver) and uterine disease are excessively common, only a minority of cows experience these problems, between herds or even within a herd in which cows apparently have similar nutritional and management experiences. Prediction or early detection of which cows have health problems is an important goal.

Interestingly, although most dairy cattle do not have the issues of obesity that preoccupy human health research, peripartum cattle do go through a period of substantial insulin resistance that has elements in common with Type 2 diabetes [6], with the important difference that cows have low blood glucose. Dairy cattle also go through a period of substantial lipolysis and a high flux of fatty acids to the liver. High circulating non-esterified fatty acid (NEFA) concentrations are a major risk factor for fatty liver and may also have direct effects on neutrophil function [7]. Because of both high metabolic demands and pathogen challenges, cattle also routinely experience substantial oxidative stress at the same time [8].

To achieve the economic objective of pregnancy within 80 to 120 days after the previous calving, the uterus must return to a condition to support a new pregnancy, and a regular estrus cycle must be re-established. This is the result of a complex set of interactions and endocrine signalling among the brain, liver, ovaries and uterus [9]. While a few research groups have begun to look at the links between energy metabolism and reproductive function, there is a gap in examining the large intervening component of uterine dis- 
ease, which is at play in as many as half of all cows. Uterine health problems (RP, metritis (uterine infection causing systemic illness in early lactation), and endometritis (chronic low-grade uterine infection and inflammation between 3 and 9 weeks postpartum) affect up to half of dairy cows in the first 60 days postpartum [10].

Retained placenta is a disease of immune function, with changes in neutrophil function and interleukin (IL)-8 levels at least two weeks before calving [4]. Cows that had RP had substantially higher serum cortisol for several days before parturition [11] which may be one contributor to impairment of neutrophil function [12]. Similarly, endometritis is associated with (preceded by) impaired innate immune function [13], and differences in IL-1, IL-6, and IL10 expression [14], again with measurable changes in phagocytosis, TNF $\alpha$ and IL-6 present prepartum [15], weeks before disease becomes manifest, coincident with the onset of insulin resistance and lipolysis (at least in cows at higher risk of disease). Cows in greater negative energy balance, and in particular those that go on to have metritis or endometritis have more pronounced impairment of at least some immune functions [5]. Cows in a greater degree of negative energy balance prepartum, as evidenced by higher nonesterified fatty acid (NEFA) concentrations were $80 \%$ more likely to have RP, and accounting for the effect of NEFA, those with lower circulating vitamin E were at greater risk of RP [16]. This supports the notion that severe negative energy balance impairs immune function, which in turn makes RP more likely, but also underlines the fact that the development of RP is multifactorial. Metabolic disease that becomes clinically manifest as displaced abomasum, typically around 10 days postpartum, is preceded by significant changes in adipose mobilization and energy metabolism up to 3 weeks before the disease event [17]. It is increasingly clear that uterine disease that is expressed 1 to 8 weeks after calving, and return to a normal estrus cycle and ovulation by 9 week after calving are preceded by metabolic and immunologic changes before and soon after calving. While metabolic and immune function can be studied in detail for research, there are indicators or surrogate measures that can be practical for clinical use.

The mechanisms of immune defence in the mammary gland, and how these are impaired in the transition period have been reviewed [18]. However, less is known about the determinants of uterine health, and how resistance to uterine disease may be enhanced through animal management. Contamination of the uterus with potentially pathogenic bacteria is nearly universal after calving [19], yet only a minority of cows develop clinical disease. Similar to RP, development of metritis depends largely on immune function in the early postpartum period [5]. Cows with severe metritis ate 2 to $6 \mathrm{~kg} /$ day DM less than healthy cows in the 2 to 3 weeks preceding the clinical signs of metritis [20]. Lower feed intake is associated with increased NEFA which contributes to the risk of fatty liver [21], which in turn is associated with impaired neutrophil function [22]. Additionally, NEFA have been shown to inhibit neutrophil function in vitro [7]. Healthy cows clear the uterus of bacteria by approximately 3 weeks postpartum but important gaps remain in understanding of the immunobiology of the reproductive tract of cattle. Approximately $17 \%$ of cows fail to clear bacterial infection and have clinical endometritis [23] and an additional 15 to $20 \%$ have chronic subclinical inflammation [24]. Both forms of endometritis are associated with substantial decreases in pregnancy rate. Recent research [25] indicates that uterine infection predominated by $E$. coli in the first week postpartum and A. pyogenes in the third week is associated with subsequent endometritis.

In summary, metabolic events starting two weeks before calving have effects on reproductive health 1 to 9 weeks after calving, which in turn have effects on reproductive performance weeks to months later. The determinants of why some cows develop uterine health problems are not well understood, which limits the ability to intervene to prevent these problems or mitigate their effects.

\section{Monitoring Programs}

\section{Objectives}

Routine, proactive actions, observations, or analysis are intended to accurately and efficiently provide early detection of problems, to provide an opportunity for investigation and intervention in order to limit the consequences and costs of health problems and reduced animal performance or welfare. There are two main reasons for monitoring transition dairy cows in general, and running metabolic tests in particular. The objectives overlap, but are distinct and should be clear before embarking on a program. The objectives are: herd or group level - to monitor the success of current management with the goal of early detection of problems or deviation from the management program; individual level-to identify cows at high risk for disease with the goal of intervention for these individuals to prevent or mitigate clinical disease.

\section{Methods of monitoring}

The principles and practice of screening programs for fresh cows have been well and critically described [26].

Clinical disease records: A starting point for assessment of peripartum health is to have accurate records of the farm-specific incidence of the clinical diseases of importance to the herd. This would typically include the number of cattle that had dystocia, RP, milk fever, metritis, and DA, or that were culled or died in early lactation divided by the number of cows that calved in a defined time period. The incidence of clinical mastitis and lameness per month or other time period is also useful although complicated by the risk period extending throughout lactation and the possibility for multiple occurrences in the same cow, which may not be independent events. For all diseases, it is important that the case definitions be clear, mutually exclusive, and consistently recorded. The records should allow for measurement of the incidence of the condition of interest, not the treatment rate (e.g. if some cases of RP are not treated the disease event should still be recorded; conversely if a condition is treated for 3 days, there should only be 1 recorded occurrence of the disease (as opposed to 3 treatment events). Investigation of the pattern of affected animals and the risk factors for disease is suggested if the following crude lactational incidence risks are exceeded: dystocia $>20 \%$; RP $>10 \%$; milk fever $>2 \%$; metritis $>10 \%$; DA $>5 \%$. However, herd size, demographics, and management influence the expected incidence, so reference to herd-specific goals and recent history are more useful than broad benchmarks. Also, tracking the rates of clinical disease is necessarily retrospective and therefore at best allows for 
reaction to problems rather than early warning. Finally, clinical disease is typically only the "tip of the iceberg" with respect to health problems and therefore these records underestimate the prevalence of potentially performance-limiting health conditions. For example, the incidence of clinical ketosis is typically reported at 5 to $10 \%[27,28]$ but if measured systematically, the incidence of subclinical ketosis in the first 3 weeks of lactation is approximately $40 \%$ [29]. Trends in the prevalence of culling in early lactation may also provide an additional element of herd-level information [30].

Measurement of feed intake: Adequate feed intake by all peripartum cattle is crucial for health and production. It is therefore desirable to measure feed dry matter intake (DMI) in prepartum and early postpartum cows. Although measurement of only group average intake may be feasible in commercial free stall barns, that is still likely to be useful information. For example, if there is $<2 \%$ of feed remaining prior to the first feeding of the next day, then ad libitum intake is likely not being achieved by all animals in the group. Assessment of individual feed intake and lack of competition for feed access are advantages of tie stall housing. Technology exists for automated capture of both individual DMI and feeding behaviour in group-housed cattle [31], and elements of such technologies may be applied on a commercial scale in the future.

Milk production: Milk production is expected to increase rapidly in early lactation, and a consistent rise should result from good health and feed intake. Therefore, automated daily measurement of milk production in the first few weeks of lactation offers promise as a means to identify cows with clinical or subclinical health problems. The variability of daily milk yield is high [32], especially in early lactation, and is influenced by many factors beyond health (e.g. weather, changes in diet, movement of cattle to new groups, etc). However, decreased milk production often precedes clinical disease, and daily yield coupled with activity monitoring may be useful for screening of cows for earlier disease detection [33]. Trends in projected production from early lactation provide herdlevel information on the success of transition into lactation [30]. New tools to compare expected to actual production in early lactation (Transition Cow Index ${ }^{\circledR}$; [34]) may also help to quantify the impact of suboptimal peripartum health and management.

Body condition scoring: Body condition scoring provides a rapid, simple, and acceptably precise estimate of body fatness [35, 36]. It reflects the nutritional, metabolic, and to some extent, health history of a cow in the preceding weeks. Numerous studies have examined the association of BCS with health and reproduction [37], and while generally cows that calve in fat body condition, or moreover cows that lose 1 point or more of BCS in early lactation, are often reported to be at higher risk of adverse outcomes, BCS alone (other than extremes i.e. $>4$ or $<2.5$ at calving) is not a sensitive or specific tool for prediction of disease or reproductive performance. Recent research has suggested that the target BCS at calving should likely be lower $(\leq 3.0)$ than previously advocated to optimize health and production [38].

\section{Screening Cows for Uterine Disease}

The pathophysiology [39], diagnostic criteria and treatment for metritis have been reviewed elsewhere [40]. Briefly, metritis may practically be identified based on at least 2 of fetid discharge, fever, and signs of systemic illness (dullness, inappetance, or decreased milk production). Daily monitoring of rectal temperature for 7 to 10 days after calving may increase the rate of diagnosis of metritis, and if this practice is implemented it should not be the sole basis for treatment with antibiotics. Routine, systematic screening of fresh cows is likely useful to increase early detection of health problems, especially in large herds, but it is likely most useful if training and experience of personnel and facilities allow for assessment of the cows' attitude, appetite, ketosis status (once or twice weekly), rumination, and abomasal displacement.

Accurate diagnosis of clinical endometritis requires examination of discharge in the vagina after a minimum of 3 weeks postpartum [23], which may be done with a vaginoscope, clean gloved hand, or a Metricheck device [41]. Subclinical endometritis is common and has substantial impacts on reproductive performance [24]. Subclinical endometritis is diagnosed by endometrial cytology obtained trans-cervically either by uterine lavage or cytobrush [42]. Neither technique is sufficiently rapid or practical for widespread use in clinical practice, although rapid cow-side tests have been explored [43].

\section{Metabolites to Measure Energy Status in Transition Cows}

Circulating concentrations of NEFA and $\beta$-hydroxybutyrate (BHB) measure aspects of the success of adaptation to negative energy balance. The concentration of NEFA reflects the magnitude of mobilization of fat from storage and mirrors DMI [44], while BHB reflects the completeness of oxidization of fat in the liver. Ketone bodies (BHB, acetone and acetoacetate) are the intermediate metabolites of oxidation of fatty acids, specifically resulting from the incomplete oxidation of fatty acids to acetyl CoA. As the supply of NEFA to the liver exceeds the ability of liver to completely oxidize the fatty acids to supply energy, the amount of ketone production increases. Ketone bodies can be used by muscle as an alternative fuel source to glucose, sparing glucose for milk production [21]. However, ketone production does not result in as much net energy release as complete oxidation of fatty acids. Additionally, increasing concentrations of ketones are thought to suppress feed intake [45].

Glucose is the primary metabolic fuel, and is absolutely required for vital organ function, fetal growth, and milk production. In dairy cows, the massive energy demand to support milk production is largely met through gluconeogenesis. Glucose concentrations are under tight homeostatic control. Therefore, although glucose has a central role in metabolism, it is a poor analyte for monitoring or investigating herd problems [46].

\section{Associations of NEFA and BHB with Disease, Production, and Reproduction}

High NEFA ( $>0.4 \mathrm{mmol} / \mathrm{l})$ in the last 7 to 10 days before expected calving is associated with: 2 to 4 times increased risk of LDA [17, 47]; 2 times increased risk of retained placenta [16, 48]; 
2 times increased of culling before 60 days in milk (DIM) and 1.5 times increased risk of culling over the whole lactation [49]; and $1.1 \mathrm{~kg} /$ day less milk production in the first 4 months of lactation [50].

Subclinical ketosis (BHB > 1200 to $1400 \mu \mathrm{mol} / \mathrm{l}$ ) in the first or second week after calving is associated with: 3 to 8 times increased risk of LDA [17, 51]; 3 times greater risk of metritis when serum BHB in week 1 was > 1200 [51]; 4 to 6 times increased risk of clinical ketosis [51; increased probability of subclinical endometritis at week 4 postpartum [5]; and increased duration and severity of mastitis [52] but not with the incidence of mastitis [51]. Milk yield at first test was reduced by $1.9 \mathrm{~kg} / \mathrm{d}$ when BHB was $>1400 \mu \mathrm{mol} / \mathrm{l}$ in week 1 and by $3.3 \mathrm{~kg} / \mathrm{d}$ when BHB was $>2000 \mu \mathrm{mol} / \mathrm{l}$ in week 2 . Cows with serum BHB $>1800 \mu \mathrm{mol} / \mathrm{l}$ in week 1 had $>300 \mathrm{~kg}$ lower projected production for the whole lactation [51].

Ketosis is associated with reduced reproductive performance, which extends its impact much longer than many producers realize. It is worth emphasizing that health in the weeks before and after calving influences reproduction at least 2 months later. Cows with milk BHB $>100 \mu \mathrm{mol} / \mathrm{l}$ in the first week postpartum were 1.5 times more likely to be anovular at 9 weeks postpartum [53]. Cows that experienced ketosis in the first two weeks of lactation had reduced probability of pregnancy at the first insemination. Furthermore, cows that had ketosis in one or both of the first two weeks after calving had a lower pregnancy rate until 140 DIM. The median interval to pregnancy was approximately 108 days in cows without ketosis, was significantly longer (124 days) in cows with ketosis in the first or second week postpartum, and tended to be longer still (130 days) in cows that had subclinical ketosis in both of the first weeks of lactation [54].

\section{Testing Strategies and Interpretation}

\section{Test selection and sampling}

Serum or plasma NEFA concentrations measured in the week before calving (samples taken 4 to 10 days before expected calving) provide a uniquely useful component of assessment of peripartum health. Unfortunately, there are presently no on-farm diagnostic tests for measurement of NEFA, which implies the cost and delay of submission of samples to a diagnostic laboratory. The concentration of NEFA typically begins to rise 2 to 4 days before, and peaks approximately 3 days after calving, but the magnitude of increase is greater, and the increase starts earlier in cows that subsequently experience metabolic disease [17]. Some [55] have advocated excluding samples taken within 2 days before calving to avoid misinterpretation of normal increases in NEFA but this may not be necessary [17].

Each of the three main ketones is present in blood, milk and urine and can be measured, but acetoacetate is volatile and unstable, and relatively difficult to measure, and is therefore not commonly used in the field to measure ketosis. BHB is the predominant ketone body in blood, where it is stable. There is some variation of BHB concentrations diurnally and with feeding. Ketones are excreted in urine, resulting in higher concentrations in urine than in blood. Therefore, other things being equal, urine tests for ketones tend to lack specificity relative to serum. BHB concen- trations in milk reflect the concentration in serum, but are only 10 to $15 \%$ as high [56]. NEFA concentrations peak just before feeding [46]. In cows fed TMR, there is a greater prevalence of elevated serum NEFA $1 \mathrm{~h}$ before first feeding than at 4 or $10 \mathrm{~h}$ after feeding but serum BHB concentrations are quite stable across these time points. For monitoring, samples should be collected at approximately the same time of day to avoid confounding of the results by diurnal or postprandial variations.

In a field study of 1010 cows in 25 herds in Ontario, the peak incidence (first diagnosis of new cases) of subclinical ketosis was $30 \%$ and occurred in the first week after calving, with few new cases beyond the third week postpartum [56]. The cumulative incidence to 9 weeks postpartum was $43 \%$. The mean incidence varied among the 25 herds from 8 to $80 \%$. In the same study, the peak prevalence (proportion of cows testing positive at a given time point) of subclinical ketosis was approximately 33\% and occurred in week 2 after calving [56]. Therefore, the first two weeks postpartum are the optimal time to test for subclinical ketosis. The median overall prevalence in the first two weeks was approximately $20 \%$. It is noteworthy that in these data there was little correlation between the incidences of clinical and subclinical ketosis. Diagnosis rates of clinical ketosis are commonly a reflection of the diagnostic criteria used (which may not be valid) and the intensity and consistency of efforts to apply these criteria. Accordingly, treatment rates for clinical ketosis often do not reflect the true incidence of ketosis [55, 56].

Numerous studies in Canada (e.g., [29]) indicate that the vast majority of subclinical ketosis occurs within the first two weeks postpartum, with few new cases thereafter. Such ketosis is associated with management in the pre-fresh, maternity, and early postfresh periods. In contrast, others (e.g., [55]) recommend including cows that are 5 to 50 DIM in testing for subclinical ketosis. He suggests that, combined with a comprehensive investigation including disease and culling records and overall assessment of nutritional and management practices, the distribution of the time postpartum at which subclinical ketosis occurs may give direction to further investigation and a working diagnosis. Specifically, he suggests that “Type I” ketosis (low blood glucose due to lack of precursors for gluconeogenesis, but no fatty liver) occurs at 3 to 6 weeks postpartum, whereas “Type II” ketosis (associated with fatty liver just before or at calving) occurs at 5 to 15 DIM. An increased number of samples and analytes would be required to attempt to discern these syndromes. Practically, recognition of when ketosis is occurring should give direction to preventive efforts. When ketosis is detected primarily in the first two weeks postpartum, emphasis should be placed on bringing cows to the dry period in moderate body condition (BCS=3 to 3.5), avoidance of excess energy intake between dry-off and 3 weeks prepartum $[57,58]$ and particularly on measures to enhance feed intake in the last few weeks before, and through the calving period. Further investigation of an elevated prevalence of ketosis in early lactation may be aided by NEFA testing of cows in the 10 days before expected calving. If there is little evidence of ketosis in the first two weeks postpartum, but an increased incidence 3 to 6 weeks postpartum, that suggests that preventive measures should be emphasize enhancing feed intake in post-fresh period. Ketosis that occurs 
Table 1. Performance of cow-side tests for detection of subclinical ketosis

\begin{tabular}{|c|c|c|c|}
\hline Test substrate & Blood & Milk & Urine \\
\hline Preferred test & $\begin{array}{l}\text { Precision XTRA } \\
\text { (MediSense, Abbott) }\end{array}$ & $\begin{array}{l}\text { Keto-Test (KetoLac BHB) } \\
\text { Sanwa Kagaku Kenkyusho Co. }\end{array}$ & $\begin{array}{l}\text { Ketostix } \\
\text { (Bayer) }\end{array}$ \\
\hline Sensitivity* & $87-93 \%$ & $\begin{array}{l}\text { At } 100 \mu \mathrm{mol} / \mathrm{l} \text { on the strip: } 83 \% \\
\text { At } 200 \mu \mathrm{mol} / \mathrm{l}: 82 \%\end{array}$ & $\begin{array}{l}\text { At “small” level, when read after } 5 \text { sec } \\
79 \%\end{array}$ \\
\hline Specificity* & $93-100 \%$ & $\begin{array}{l}\text { At } 100 \mu \mathrm{mol} / \mathrm{l} \text { on the strip: } 54 \% \\
\text { At } 200 \mu \mathrm{mol} / \mathrm{l}: 94 \%\end{array}$ & $96 \%$ \\
\hline Approximate cost** & $\$ 2-4 /$ test; $\$ 40$ for the meter & \$2/test & $\$ 0.25 /$ test \\
\hline Validation & Iwerson et al, 2009 [68] & Summarized by Oetzel 2004 [55] & Carrier et al, 2004 [69] \\
\hline Comments & $\begin{array}{l}\text { Glucose tests available for this meter } \\
\text { are less accurate in cattle than the } \\
\text { BHB strips }\end{array}$ & $\begin{array}{l}\text { Bioketone }{ }^{\circledR} \text { powder (relative to serum } \\
\text { BHB } \geq 1200 \mu \mathrm{mol} / \mathrm{l} \text { ): sensitivity }=28 \% \\
\text { and specificity }=100 \% \text { (Geishauser } \text { et al, } \\
\text { 2000). The lack of sensitivity (too many } \\
\text { false negatives) makes this test unsuitable } \\
\text { for monitoring programs. }\end{array}$ & $\begin{array}{l}\text { Typically only able to induce } 50 \% \text { of } \\
\text { cows to urinate when sampling. } \\
\text { Acetest } ₫ \text { tablet sensitivity }=100 \% \text { but } \\
\text { specificity }=59 \% \text { (Nielen } \text { et al, 1994). } \\
\text { The lack of specificity (too many false } \\
\text { positives) makes this test unsuitable for } \\
\text { monitoring for ketosis. }\end{array}$ \\
\hline
\end{tabular}

* Relative to serum BHB $\geq 1400 \mu \mathrm{mol} / \mathrm{l}$ measured in a diagnostic laboratory. ** Based on costs in Canada.

Test characteristics varied somewhat among studies, apparently largely as a function of the prevalence of subclinical ketosis among the cows being tested. As the prevalence increases, the sensitivity is generally greater, and the specificity lower. For confirmation of a diagnosis of clinical ketosis, all of these tests would be acceptable, and the performance of milk powders is also adequate.

later than the first two to three weeks of lactation may also be associated with failure to meet the nutritional needs of cows with high production, or with poorly fermented wet grass or legume silage with high levels ( $>0.5$ to $1 \%$ of dry matter) of butyric acid. Further research to describe the occurrence of subclinical ketosis under different management conditions is warranted. Until such data are available, present evidence indicates that most subclinical ketosis occurs in the first two weeks after calving. Therefore, testing programs with the objective of monitoring the prevalence of subclinical ketosis should focus on the first two weeks after calving.

Used with knowledge of their test characteristics to inform interpretation, serum BHB, whole blood BHB measured with Precision $\mathrm{XTRA}^{\circledR}$, milk BHB measured with Keto-Test ${ }^{\circledR}$, or Ketostix ${ }^{\circledR}$ in urine (Table 1) are valid diagnostic tests for subclinical ketosis. These 3 cow-side tests are economical, practical and sufficiently accurate relative to laboratory analysis of serum for use in the field. Selection of the 100 or $200 \mu \mathrm{mol} / \mathrm{l}$ cut-point for classification of the Keto-Test ${ }^{\circledR}$ will depend on the objective of the testing. If the objective is group-level monitoring for early detection of increased prevalence of ketosis (as a reflection of the general success of transition management), then greater sensitivity is desirable and the $100 \mu \mathrm{mol} / \mathrm{l}$ should be used. If the objective is to select individual cows for treatment with the goal of preventing clinical disease, then fewer false positives may be desirable and the $200 \mu \mathrm{mol} / \mathrm{l}$ cut-point would be appropriate.

\section{Sample handling}

Serum or plasma is acceptable for BHB and NEFA testing. BHB may be falsely elevated by hemolysis in the sample [56] and NEFA results may not be accurate if there is more than mild hemol- ysis [59]. NEFA concentrations could be slightly falsely elevated if serum were not separated within 12-24 h of blood collection, or if samples were not kept chilled [60]. Serum can be kept frozen for at least 1 month without affecting NEFA results. Samples should be collected from the tail vein (not the milk vein) and ideally chilled, separated within a few hours, and then frozen or shipped chilled for receipt at the laboratory within 1 to 2 days. However, delay of up to 24 hours for separation, and maintenance at room temperature for 1 day or refrigerated for $<3$ days does not substantially affect results [60].

\section{Number of Samples and Interpretation}

The number of samples required for group or herd-level interpretation depends on the prevalence of affected animals that is judged important to detect, the certainty of detection that is desired, and the size of the group of interest [61]. Fortunately, the latter criterion has the least influence. Examples are given in Table 2. Practically, the minimum number of samples is 5, and 10 to 12 samples will allow for interpretation in most situations. Typically, 18 to $35 \%$ of cows have NEFA $>0.4 \mathrm{mmol} / \mathrm{l}$ in the last week before calving [17, 55]. Based on clinical experience, Oetzel [55]; suggests an "alarm" threshold of $10 \%$ prevalence of subclinical ketosis, based on serum BHB. Published reports indicate a typical prevalence of subclinical ketosis of around 15\% [55] studies in Canada have found average prevalence of $20 \%$ [17, 29]. Adjusting for cow-side test performance, a threshold of $10 \%$ true prevalence of subclinical ketosis corresponds to an apparent prevalence (proportion of tests that are positive) of $25 \%$ when using the Keto-Test ${ }^{\circledR}$ with a $100 \mu \mathrm{mol} / \mathrm{l}$ cut-point, or $11 \%$ at the $200 \mu \mathrm{mol} / \mathrm{l}$ cut-point [55].

It is important to interpret both NEFA and ketosis tests as the 
Table 2. Examples of the number of cows that need to be sampled as part of a routine monitoring program or to investigate a suspected problem of ketosis in a dairy herd

\begin{tabular}{|c|c|c|c|}
\hline $\begin{array}{l}\text { Number of animals in the group } \\
\text { of interest (for ketosis, typically } \\
\text { the first 2,or at most } 5 \text {, } \\
\text { weeks of lactation) }\end{array}$ & $\begin{array}{l}\text { Estimated prevalence of the } \\
\text { condition (What prevalence } \\
\text { is it important to detect?) }\end{array}$ & $\begin{array}{l}\text { Confidence (How certain do you } \\
\text { wish to be of detecting that } \\
\text { the prevalence of interest } \\
\text { has been reached?) }\end{array}$ & $\begin{array}{c}\text { Number of samples } \\
\text { required }\end{array}$ \\
\hline 10 & 10 & 75 & 8 \\
\hline 10 & 10 & 95 & 10 \\
\hline 10 & 20 & 75 & 5 \\
\hline 10 & 20 & 95 & 8 \\
\hline 50 to 1000 & 10 & 75 & 12 \\
\hline 50 to 1000 & 10 & 95 & 14 \\
\hline 50 to 1000 & 20 & 75 & $6-7$ \\
\hline 50 to 1000 & 20 & 95 & $12-14$ \\
\hline 50 to 1000 & 30 & 95 & 9 \\
\hline
\end{tabular}

proportion of animals above a meaningful threshold because this best describes the biology of the condition. It is misleading to calculate the average BHB or NEFA from a group of samples and similarly most information is lost if samples from multiple animals are pooled together.

\section{Investigation of underlying causes, and intervention}

Several practical guidance documents for investigation of health problems in transition dairy cows by veterinary practitioners or other advisors have been put forward [62-66]. The critical principles are to investigate and ensure that all cattle have unrestricted access to feed at the time of fresh feed delivery, to clean water, and to a comfortable resting place. Unfortunately, there is presently little evidence to inform choices of intervention in individual cows in response to elevated NEFA or BHBA. Administration of propylene glycol, insulin, or corticosteroids might be beneficial, but further research is needed on treatment regimes that might be effective at reducing the risk of disease or reduced performance among cows identified at high risk of these problems. Based on currently available data [67], propylene glycol may be a reasonable treatment for cows with elevated NEFA or BHB.

\section{Conclusions}

Undesirably elevated concentrations of NEFA and subclinical ketosis are prevalent and important conditions associated with increased risk of metabolic and uterine disease, decreased milk production, and decreased reproductive performance. Measurement of the prevalence of subclinical ketosis in the first 2 weeks of lactation is useful for investigation of herd problems of transition cow health and performance, and for routine monitoring. The timing, magnitude, and duration of peripartum increases in circulating concentrations of NEFA and BHBA are associated with the risk of abomasal displacement, uterine disease, and reproductive performance from 1 through 20 weeks later. Programs to monitor management of the transition period may usefully include NEFA concentrations in the week before expected calving and BHB concentration in the first week after calving. A key link among diseases is feed intake. Peripartum energy metabolism and immune function will plausibly be favoured when cows have unrestricted access to diets formulated to meet nutrient requirements and to water in the transition period. Proactive management and investigation of problems should focus on minimizing nutritional, housing, social, and environmental factors that may impair feed and resting access for all or some members of the groups of peripartum cows.

\section{References}

1. Bauman DE. Regulation of nutrient partitioning during lactation: Homeostasis and homeorhesis revisited. In: Ruminant Physiology: Digestion, Metabolism, Growth and Reproduction. CAB; 2000.

2. Kehrli ME, Nonecke BJ, Roth JA. Alterations in bovine neutrophil function during the periparturient period. Am J Vet Res 1989; 50: 207-214.

3. Goff JP, Horst RL. Physiological changes at parturition and their relationship to metabolic disorders. J Dairy Sci 1997; 80: 1260-1268.

4. Kimura K, Goff JP, Kehrli ME, Reinhardt TA. Decreased neutrophil function as cause of retained placenta in dairy cattle. J Dairy Sci 2002; 85: 544-550.

5. Hammon DS, Evjen IM, Dhiman TR, Goff JP, Walters JL. Neutrophil function and energy status in Holstein cows with uterine health disorders. Ve Immunol Immunopath 2006; 113: 21-29.

6. Lucy M. Mechanisms linking the somatotropic axis with insulin: Lessons from the postpartum dairy cow. Proc NZ Soc Anim Prod 2004; 64: 19-23.

7. Scalia D, Lacetera N, Bernabucci U. In vitro effects of nonesterified fatty acids on bovine neutrophils oxidative burst and viability. J Dairy Sci 2006; 89: 147-154.

8. Sordillo LM, Aitken SL. Impact of oxidative stress on the health and immune function of dairy cattle. Vet Immunol Immunopath 2009; 128: 104-109.

9. Wathes DC, Fenwick M, Cheng Z, Bourne N, Llewellyn S, Morris DG, Kenny D, Murphy J, Fitzpatrick R. Influence of negative energy balance on cyclicity and fertility in the high producing dairy cow. Theriogenology 2007; 68: S232-S241.

10. Sheldon IM, Lewis GS, LeBlanc S, Gilbert R. Defining post partum uterine disease in cattle. Theriogenology 2006; 65:1516-1530.

11. Peter AT, Bosu WTK. Peripartal changes associated with retained placenta in dairy cows. Theriogenology 1987; 28: 383-394.

12. Burton JL, Kehrli ME, Kapil S, Horst RL. Regulation of L-selectin and CD18 on bovine neutrophils by glucocorticoids: effects of cortisol and dexamethasone. J Leuk Biol 1995; 57: 317-325.

13. Sheldon IM, Cronin J, Goetze L, Herath S. Defining postpartum uterine disease and the mechanisms of infection and immunity in the female reproductive tract in cattle. Biol Reprod 2009.DOI:10.1095/biolreprod.109.077370

14. Herath S, Lilly ST, Santos NR, Gilbert RO, Sheldon IM. Expression of genes associated with immunity in the endometrium of cattle with disparate postpartum uterine disease and fertility. Reprod Biol Endocrin 2009; 7: 55.

15. Kim IH, Na KJ, Yang MP. Immune responses during the peripartum period in dairy cows with postpartum endometritis. J Reprod Dev 2005; 51: 757-764

16. LeBlanc SJ, Herdt T, Seymour W, Duffield T, Leslie K. Factors associated with peri- 
partum serum concentrations of vitamin E, retinol, and $\beta$-carotene in Holstein dairy cattle, and their associations with periparturient disease. J Dairy Sci 2004; 87: 609-619.

17. LeBlanc SJ, Leslie KE, Duffield TD. Metabolic predictors of displaced abomasum in dairy cattle. J Dairy Sci 2005; 88: 159-170.

18. Burvenich C, Bannerman DD, Lippolis JD, Peelman L, Nonneckne BJ, Kehrli ME Jr, Paape MJ. Cumulative physiological events influence the inflammatory response of the bovine udder to E. coli infections during the transition period. J Dairy Sci 2007; 90 (Suppl 1): E39-E54.

19. Sheldon IM, Dobson H. Postpartum uterine health in cattle. Anim Reprod Sci 2004; 82-83: 295-306.

20. Huzzey JM, Veira DM, Weary DM, von Keyserlingk MAG. Prepartum behavior and DMI identify dairy cows at risk for metritis. J Dairy Sci 2007; 90: 3220-3233.

21. Herdt TH. Ruminant adaptation to negative energy balance. Vet Clin North Am Food Anim Pract 2000; 16: 215-230.

22. Zerbe H, Schneìder N, Leibold W, Wensing T, Kruip TA, Schuberth HJ. Altered functional and immunophenotypical properties of neutrophilic granulocytes in postpartum cows associated with fatty liver. Theriogenology 2000; 54: 771-786.

23. LeBlanc SJ, Duffield T, Leslie K, Bateman K, Keefe G, Walton J, Johnson W. Defining and diagnosing postpartum clinical endometritis, and its impact on reproductive performance in dairy cows. J Dairy Sci 2002; 85: 2223-2236.

24. Gilbert RO, Shin ST, Guard CL, Erb HN, Frajblat M. Prevalence of endometritis and its effects on reproductive performance of dairy cows. Theriogenology 2005; 64: 18791888 .

25. Santos NR, Galvão KN, Brittin SB, Gilbert RO. The significance of uterine E. coli infection in the early postpartum period of dairy cows. Reprod Dom Anim 2008; 43 Supp1: 63 (abstr)

26. Guterbock WM. Diagnosis and treatment programs for fresh cows. Vet Clin Food Anim 2004; 20: 605-626

27. Kelton DF, Lissemore KD, Martin RE. Recommendations for recording and calculating the incidence of selected clinical diseases of dairy cattle. J Dairy Sci 1998; 81:25022509.

28. Zwald NR, Weigel KA, Chang YM, Welper RD, Clay JS. Genetic selection for health traits using producer-recorded data. I. Incidence rates, heritability estimates, and sire breeding values. J Dairy Sci 2004; 87: 4287-4294.

29. Duffield TF, Sandals D, Leslie KE, Lissemore K, McBride BW, Lumsden JH, Dick P, Bagg R. Efficacy of monensin for the prevention of subclinical ketosis in lactating dairy cows. J Dairy Sci 1998; 81: 2866-2873.

30. Nordlund KV, Cook NB. Using herd records to monitor transition cow survival, productivity, and health. Vet Clin Food Anim 2004; 20: 627-649.

31. Chapinal N, Veira DM, Weary DM, von Keyserlingk MAG. Validation of a system for monitoring individual feeding and drinking behavior and intake in group-housed cattle. J Dairy Sci 2007; 90: 5732-5736.

32. Quist MA,LeBlanc SJ, Hand KJ,Lazenby D, Miglior F, Kelton DF. Milking-to-milking variability for milk yield, fat and protein percentage, and somatic cell count. $J$ Dairy Sci 2008; 91: 3412-3423.

33. Edwards JL, Tozer PR. Using activity and milk yield as predictors of fresh cow disorders. J Dairy Sci 2004; 87: 524-531.

34. Nordlund K. Transition Cow Index ${ }^{\mathrm{TM}}$. Proc Am Assoc Bov Pract 2006; 39: 139-143.

35. Edmonson AJ, Lean IJ, Weaver LD, Farver T, Webster G. A body condition scoring chart for Holstein dairy cows. J Dairy Sci 1989; 72: 68-78

36. Ferguson JD, Galligan DT, Thomsen N. Principal descriptors of body condition score in Holstein cows. J Dairy Sci 1994; 77: 2695-2703.

37. Bewley JM, Schutz MM. Review: An interdisciplinary review of body condition scoring for dairy cattle. Professional Animal Scientist 2008; 24: 507-529.

38. Garnsworthy P. Influences of body condition on fertility and milk yield. In: Proc Dairy Cattle Reproduction Council Convention 2008; 63-72.

39. Sheldon IM, Williams EJ, Miller ANA, Nash DM, Herath S. Uterine diseases in cattle after parturition. The Veterinary Journal 2008; 176: 115-121.

40. LeBlanc S. Postpartum uterine disease and dairy herd reproductive performance-A review. The Veterinary Journal 2008; 176: 102-114.

41. Pleticha S, Drillich M, Heuwieser W. Evaluation of the Metricheck device and the gloved hand for the diagnosis of clinical endometritis in dairy cows. J Dairy Sci 2009; 92: 5429-5435.

42. Barlund CS, Carruthers TD, Waldner CL, Palmer CW. A comparison of diagnostic techniques for postpartum endometritis in dairy cattle. Theriogenology 2008; 69: 714-
723.

43. Santos NR, Roman HB, Gilbert RO. The use of leukocyte esterase reagent strips for diagnosis of subclinical endometritis in dairy cows. Theriogenology 2006; 66: 666-667.

44. Adewuyi AA, Gruys E, van Eerdenburg FCM. Non esterified fatty acids (NEFA) in dairy cattle. A review. Vet Q 2005; 27: 117-126.

45. Allen MS, Bradford BJ, Oba M. The hepatic oxidation theory of the control of feed intake and its application to ruminants. J Anim Sci 2009; 87:3317-3334.

46. Herdt TH. Variability characteristics and test selection in herd-level nutritional metabolic profile testing. Vet Clin North Am Food Anim Pract 2000; 16: 387-403.

47. Cameron, REB, Dyk PB, Herdt TH, Kaneene JB, Miller R, Bucholtz HF, Liesman JS Vandehaar MJ, Emery RS. Dry cow diet, management, and energy balance as risk factors for displaced abomasum in high producing dairy herds. J Dairy Sci 1998; 81: 132 139

48. Quiroz-Rocha GF, LeBlanc SJ, Duffield T, Wood D, Leslie K, Jacobs RM. Evaluation of prepartum serum cholesterol and fatty acids concentrations as predictors of postpartum retention of the placenta in dairy cows. J Am Vet Med Assoc 2009; 234: 790-793.

49. Duffield T, LeBlanc S, Leslie K. Impact of subclinical metabolic disease on risk of early lactation culling. J Dairy Sci 2005; 88(Suppl 1): 199 (abstr.).

50. Carson ME. The association of selected metabolites in peripartum dairy cattle with health and production. MSc Thesis, University of Guelph, 2008.

51. Duffield TF, Lissemore KD, McBride BW, Leslie KE. Impact of hyperketonemia in early lactation dairy cows on health and production. J Dairy Sci 2009; 92: 571-580.

52. Suriyasathaporn W, Heuer C, Noordhuizen-Stassen EN, Schukken YH. Hyperketonemia and udder defense: a review. Vet Res 2000; 31: 397-412.

53. Walsh RB, Kelton DF, Duffield, Leslie KE, Walton JS, LeBlanc SJ. Prevalence and risk factors for postpartum anovulatory condition in dairy cows. J Dairy Sci 2006; 90 : 315-324

54. Walsh R, Leslie K, LeBlanc S, Kelton D, Walton J, Duffield T. The effect of subclincial ketosis in early lactation on reproductive performance of postpartum dairy cows J Dairy Sci 2007; 90: 2788-2796.

55. Oetzel GR. Monitoring and testing dairy herds for metabolic disease. Vet Clin N Amer Food Anim 2004; 20: 651-674.

56. Duffield T. Subclinical ketosis in lactating dairy cattle. Vet Clin N Amer-Food Anim 2000; 16: 231-253.

57. Dann HM, Litherland NB, Underwood GP, Douglas G, Drackley JK. Diets during far-off and close-up dry periods affect periparturient metabolism and lactation in multiparous cows. J Dairy Sci 2006; 89: 3563-3577.

58. Drackley JK, Janovick-Guretzky NA, Dann HM. New approaches to feeding dry cows. In: Proc Tri-State Dairy Nutrition Conference. Fort Wayne, Indiana, 2007.

59. Stokol T, Nydam DV. Effect of hemolysis on nonesterified fatty acid and _b-hydroxybutyrate concentrations in bovine blood. J Vet Diagn Invest 2006; 18: 466-469.

60. Stokol T, Nydam DV. Effect of anticoagulant and storage conditions on bovine nonesterified fatty acid and $\beta$-hydroxybutyrate concentrations in blood. J Dairy Sci 2005 88: 3139-3144.

61. Dohoo I, Martin W, Stryhn H. Veterinary Epidemiologic Research. Charlottetown PEI, Canada, 2003: AVC Inc.

62. Cook NB, Nordlund KV. Behavioral needs of the transition cow and consideration for special needs facility design. Vet Clin Food Anim 2004.; 20: 495-520.

63. Mulligan FJ, O'Grady L, Rice DA, Doherty ML. A herd health approach to dairy cow nutrition and production diseases of the transition cow. Anim Reprod Sci 2006; 96: 331353

64. Nordlund K, Cook N, Oetzel G. Commingling dairy cows: Pen moves, stocking density, and health. In: Proc American Association Bovine Practitioners. St. Paul, MN. 2006; 39: 36-42

65. Nordlund K. Fresh cow programs: The key factors to prevent poor transitioning cows In: Proc 2008 Dairy Council Reproduction Council Convention: 73-76.

66. O'Boyle N. Nutrition of the periparturient dairy cow. In Practice 2008; 30: 495-500.

67. Nielsen NI, Ingvartsen KL. Propylene glycol for dairy cows - A review of the metabolism of propylene glycol and its effects on physiological parameters, feed intake, milk production and risk of ketosis. Anim Feed Sci Tech 2004. 115: 191-213.

68. Iwersen M, Falkenberg U, Voigtsberger R, Heuwieser W. Evaluation of an electronic cowside test to detect subclinical ketosis in dairy cows. J Dairy Sci 2009; 92: 2618-2624.

69. Carrier JS, Stewart S, Godden S, Fetrow J, Rapnicki P. Evaluation and use of three cowside tests for detection of subclinical ketosis in early postpartum cows. J Dairy Sci 2004; 87 : 3725-3735. 